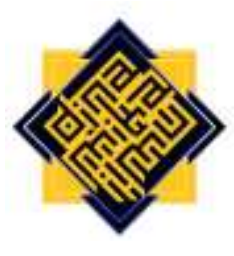

\title{
Entrepreneurship Learning Model to Improve the Competence of Vocational Students at the Islamic University of Indonesia
}

\author{
Istiningsih \\ State Islamic University (UIN) of Sunan Kalijaga Yogjakarta Indonesia \\ e-mail: istiningsih@uin.suka.ac.id
}

\begin{abstract}
:
Entrepreneurship is one of the spearheads of the economy so it is important to provide entrepreneurship education and one of them is in higher education. With entrepreneurship education, students create jobs and reduce the numbers given. The purpose of this study is to develop an effective entrepreneurship learning model by analyzing the role of lecturer experience and internship programs on student entrepreneurial competencies. The research method used is quantitative research with primary data based on the results of research in the field using instruments such as rt to partially or simultaneously test the developed model. The results of the research, the experience of lecturers in carrying out entrepreneurial activities and industrial internship programs for students partially or simultaneously have a positive effect on the competence of students in the vocational department of the Islamic University of Indonesia.
\end{abstract}

Keywords: entrepreneurship learning model, internship, vocational students 
Istiningsih

\section{A. Introduction}

Entrepreneurship is the spearhead in a country's economy in order to increase longterm economic growth, economic prosperity, and social prosperity through increasing state income (Naudé, 2010). The role of entrepreneurship is so important that many countries seek for their citizens to have their own businesses rather than working under someone else's leadership (Boldureanu et al., 2020). One of the abilities of a person in entrepreneurship is the need for motivation to do this. With the motivation and movement to do entrepreneurship, it can reduce unemployment and increase employment so that entrepreneurship learning becomes important (Mustikawati \& Kurjono, 2020).

Entrepreneurship learning is an important factor in order to grow and develop the desire, behavior, and entrepreneurial spirit, especially among the younger generation (Genoveva, 2019). This is because education is one source of the overall attitude and intention to become an entrepreneur (Martyajuarlinda \& Kusumajanto, 2018). In educational institutions, entrepreneurship learning is given in several majors, both at the level of SMK or tertiary institutions. Even in universities, entrepreneurship education is in various departments and faculties as one of the subjects.

Entrepreneurship education in higher education has been facilitated by the Ministry of Education and Culture, Research and Technology, Republic of Indonesia (Kemendibudristek) since 1997 with the existence of entrepreneurship development programs in universities such as entrepreneurship courses, internships, and so on. Then in 2009, Higher Education provided a scheme for students who were interested in becoming job creators through the entrepreneurial student program. These policies are implemented so that graduates can implement their abilities, expertise, and teamwork in the field of science they are engaged in. This situation is in line with Government regulations No. 17 of 2010 which states that the purpose of higher education is to form critical, creative, innovative, independent, confident, and entrepreneurial people (Susilaningsih, 2015).

The existence of entrepreneurship education is often connoted as business education that contains materials and activities related to building an entrepreneurial mental attitude, training communication skills, building networks, and preparing business plans with a profit orientation (Elwanas, 2020). Therefore, it is not surprising that universities require entrepreneurship courses for students even though there are several faculties or study programs that refuse or do not agree with the policy. However, in vocational education, it becomes important.

Vocational education at universities is important to get entrepreneurship courses (Abdullah, 2020). This situation is motivated because vocational education has the aim of preparing human resources who have expertise and skills in their fields so that they are more ready to work (Mayani \& Syamsudin, 2011). Vocational education such as diploma 1, diploma 2, diploma 3, diploma 4, applied bachelor, applied master, and applied doctoral programs (Kemenristekdikti, 2019). The function of entrepreneurship in vocational education is that in addition to students being able to develop their knowledge, they are also able to implement it in the business world which ends in profit (Bagus et al., 2015). So 
that students who graduate from vocational education can not only work in their fields but can open businesses according to their fields and open up job opportunities for other people (Sukoco et al., 2019).

The existence of vocational education will prepare graduates with the skills, abilities, understanding, behavior, attitudes, and habits towards jobs that are needed by people in the industrial world. However, so far, the majority of vocational education is more about being ready to work in a particular industry, not opening up business opportunities or doing business, while knowledge in vocational education is applied to entrepreneurship. This can be motivated by several things, one of which is the lack of entrepreneurial competence of vocational education students.

Lack of entrepreneurial competence can be influenced by the experience of lecturers in teaching entrepreneurship and internships in the industry. The experience of lecturers in providing entrepreneurship education to students is important because lecturers can share their experiences in building a particular business. In addition, internships in industries according to student fields can open students' mindsets about the world of entrepreneurship and how to run a business. As in vocational education students at the Islamic University of Indonesia who have entrepreneurship courses in order to build skills and expertise that can be applied to the business world.

In a previous study by Maula (2017) that the entrepreneurial experience will determine the entrepreneurial characteristics of students and develop student competencies in their fields. Other than that, Andayani (2015), in her research, stated that entrepreneurship learning experiences for teachers can help students grow an interest in entrepreneurship so that after graduation they can understand the business world and even create jobs. The experience of educators who have an entrepreneurial spirit can increase students' interest in entrepreneurship due to seeing examples of educator success (Mudawama, 2018). By looking at the previous research, it shows that with the experience of educators regarding entrepreneurship, it is important to encourage students to have an entrepreneurial spirit and increase self-competence in entrepreneurial activities.

Then regarding internships in the industrial world as in research Rifa'i \& Nugraha (2019) that by applying internships to students in higher education as a continuous learning process with entrepreneurship education, it can form student competencies to carry out entrepreneurship activities and reduce unemployment. Then research Elizar (2018) mentions if it is necessary to develop entrepreneurship programs in universities in order to improve student entrepreneurial competencies in order to form successful young entrepreneurs. Study (Prabandari \& Rasyid, 2015) mentions that entrepreneurship learning through work practices or internships has a strong influence on entrepreneurial competence. The purpose of this study is to develop an effective entrepreneurship learning model by analyzing the role of lecturer experience and internship programs on student entrepreneurial competencies. 
Istiningsih

\section{B. Literature Review}

Entrepreneurship education or entrepreneurship courses are generally only for certain faculties or majors. Not all majors have the same perspective in allocating credits to present this course. It is necessary to find agreement and common ground about the need for entrepreneurship courses in all existing departments or study programs (Banu, 2009).

Entrepreneurship education helps build character and entrepreneurial spirit and instills entrepreneurial competencies and values (Yohana, 2020). The role of the university is expected to open students' understanding and perception of the entrepreneurial world so that students have created and spur their creative ideas (Nurjaya et al., 2020). Students are expected not to be fixated on activities looking for work after graduating from college, but they can create jobs with the entrepreneurial skills they have learned on campus (Muhson et al., 2012).

Entrepreneurship education is important to be taught to learn things related to entrepreneurship as a provision before starting a business or business (Buana et al., 2017). The objectives of entrepreneurship education according to the Directorate General of Learning and Student Affairs of the Ministry of Research, Technology and Higher Education are to build soft skills or entrepreneurial character, to develop new entrepreneurs who are highly educated and have a mindset of creating jobs, to encourage growth, development or the formation of entrepreneurial institutions in higher education, and encourage the formation of an entrepreneurship education model in higher education.

Entrepreneurial competence is a combination of attitudes, knowledge, and skills that are interconnected because they are needed to achieve good performance in running their business (Sugandi \& Suhaeni, 2019). Entrepreneurial competence will affect the level of success of the business being run so that a business without competence can make the business not run smoothly (Kyguolienè \& Švipas, 2019).

Experienced lecturers or practitioner lecturers are lecturers who already have business experience. Practicing lecturers have a very good experience when they are able to pass it on to students. The experience is obtained based on the time used by the lecturer to acquire knowledge, skills, and attitudes according to the frequency and type of assignment. This experience will increasingly have mastery and skills in the field and become the main capital to persevere in the field (Samuel, 2014).

The entrepreneurship internship program is an activity for students to gain practical work experience in small and medium enterprises including problem identification, analysis, and problem-solving, as well as management, marketing, and technology (Banu, 2009). Entrepreneurship internships are activities where students actually work as workers which will create linkages and equivalence between universities and industry (Disas, 2018).

The literature explains that entrepreneurship has an important role in increasing local revenue (Naudé, 2010). In addition, entrepreneurship is able to make a person independent. They do not depend on others, and others depend on them (Boldureanu et al., 2020). In doing business, business people need to conduct comparative studies with other entrepreneurs who have been successful. Thus, good ideas emerge for students, 
which in turn will be able to reduce students' good intentions to do business and reduce unemployment (Mustikawati \& Kurjono, 2020).

In the process of inculcating entrepreneurial skills in students, an apprenticeship process can be easily carried out. With this apprenticeship, students are better prepared to open their own businesses (Genoveva, 2019). Through the apprenticeship process, students become more aggressive in knowing the steps that must be taken in order to improve entrepreneurial competence (Martyajuarlinda \& Kusumajanto, 2018).

All educational institutions need to conduct apprenticeship programs so that all students can easily learn about various things to be able to open independent businesses both during college and after they graduate. (Susilaningsih, 2015). Since college students can also learn to do business without disturbing the ongoing lecture process so that an entrepreneurial spirit is formed among students (Taufik, 2019).

Entrepreneurship education is very important in the process of building the mental attitude to continue to grow and the mental attitude to dare to take risks, dare to work hard, dare to compete with competitors, and be able to take the right opportunity (Elwanas, 2020). This is why entrepreneurship education is important to be given to students so that in the future these students will not depend on the formation of civil servants, large companies, and other business people (Abdullah, 2020).

With good experience, students are able to develop it in a very challenging business world because the competition is very tough (Diana et al., 2010). Students become ready to work, ready to compete, and ready to win in the competition (Mayani \& Syamsudin, 2011). Vocational education in higher education must be able to prepare graduates to be ready to work and do business (Kemenristekdikti, 2019). In addition, you must be able to read the business opportunities that provide the best future (Bagus et al., 2015). Vocational students must be able to open businesses that can open job vacancies, not increase unemployment (Sukoco et al., 2019).

Maula (2017) students must be able to become leaders in their fields, not only be able to become workers in other people's companies. Therefore, a very meaningful learning experience is needed that is able to provide encouragement to vocational college alumni to open a business independently (Andayani, 2015). Good experience when participating in internships also has a significant impact on students to open independent businesses (Mudawama, 2018). The literature mentions that internships have a positive impact on the success of Vocational College alumni (Rifa'i \& Nugraha, 2019). At the time of internship, students are trained with a variety of excellent experiences (Elizar, 2018). In addition, internship practices can generate various innovative inspirations for students to apply in their business ventures in the future (Prabandari \& Rasyid, 2015).

\section{Research Methodology}

\section{Research Design}

This study aims to determine and describe the effect of the experience of lecturers and industrial internships on the entrepreneurial competence of vocational students at the Islamic University of Indonesia. Based on the research objectives, the research design used 
Istiningsih

is quantitative. The quantitative approach was chosen because this study wanted to test a model that had been prepared based on theory. The research location is at Universitas Islam Indonesia.

\section{Respondent}

The participants in this study were all vocational students at the Islamic University of Indonesia as many as 100 respondents were taken using a random sampling technique.

\section{Data and Sources of Data}

This research consists of primary data which is a questionnaire with a Likert scale and distributed to respondents.

\section{Indicator of Variable}

Table 1. Indicator of Variable

\begin{tabular}{|c|c|c|}
\hline Variable & Indicator & No. \\
\hline \multirow{5}{*}{$\begin{array}{l}\text { practitioner } \\
\text { lecturer }\left(\mathrm{X}_{1}\right)\end{array}$} & Have business experience (entrepreneur) & PL1 \\
\hline & Have entrepreneurial goals and objectives & PL2 \\
\hline & Finish the job well & $\mathrm{PL} 3$ \\
\hline & Don't make mistakes in entrepreneurship & $\mathrm{PL}_{4}$ \\
\hline & Understanding about the industrial market & $\mathrm{PL} 5$ \\
\hline \multirow{6}{*}{$\begin{array}{l}\text { Industrial work } \\
\qquad\left(\mathrm{X}_{2}\right)\end{array}$} & Skill mastery & $\mathrm{IW}_{1}$ \\
\hline & Attitudes and behavior in harmony with the world of work & $\mathrm{IW}_{2}$ \\
\hline & Discipline and responsibility & $\mathrm{IW}_{3}$ \\
\hline & Creativity & $\mathrm{IW}_{4}$ \\
\hline & Independence & $\mathrm{IW}_{5}$ \\
\hline & Teamwork & IW6 \\
\hline \multirow{10}{*}{$\begin{array}{c}\text { Entrepreneurship } \\
\text { Competence }(\mathrm{Y})\end{array}$} & Entrepreneurship knowledge & $E C_{1}$ \\
\hline & Entrepreneurial Attitude/Mindset & $E C_{2}$ \\
\hline & Ability to control risk & $E C_{3}$ \\
\hline & Search and analyze information & $\mathrm{EC}_{4}$ \\
\hline & Communication & $\mathrm{EC}_{5}$ \\
\hline & Building a social network & EC6 \\
\hline & Innovation & $E C_{7}$ \\
\hline & Integrity & EC8 \\
\hline & Leadership & EC9 \\
\hline & Responsible & $E C_{10}$ \\
\hline
\end{tabular}

\section{Validity Test}

The validity test in this study uses the Smart PLS application with the outer Loadings analysis method as follows:

Table 2. Outer Loadings

\begin{tabular}{|c|c|c|c|c|}
\hline Variable & $\begin{array}{c}\text { No. } \\
\text { Item }\end{array}$ & $\mathbf{X}_{1}$ & $\mathbf{X}_{2}$ & Y \\
\hline $\begin{array}{l}\text { Practitioner } \\
\text { Lecturer }(\mathrm{X})\end{array}$ & 1 & 0,985 & & \\
\cline { 2 - 5 } & 2 & 0,748 & & \\
\hline
\end{tabular}




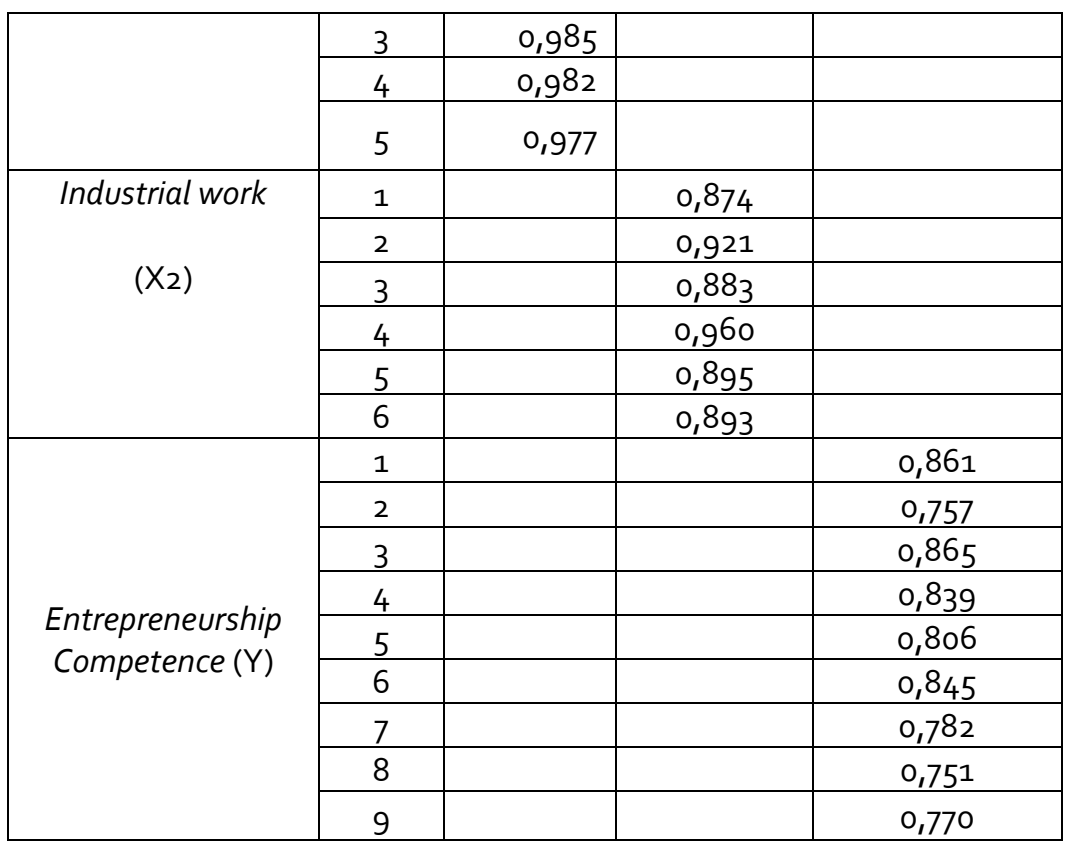

Based on the results of the validity test, it shows that all $r$ values are greater than 0.7 so it can be said that all of the questionnaire items are valid.

\section{Reliability test}

In this study, the reliability test was carried out using composite reliability and Cronbach's alpha. The decision criteria for reliability testing with composite reliability can be seen as follows: If the composite reliability value is $>0.7$, then the questionnaire item is reliable. If the composite reliability value is $<0.7$, then the questionnaire item is not reliable. The following is the result of the calculation of composite reliability.

Table 3. Reliability test

\begin{tabular}{lllll}
\hline Variable & $\begin{array}{l}\text { Cronbach's } \\
\text { Alpha }\end{array}$ & rho_A & $\begin{array}{l}\text { Composite } \\
\text { Reliability }\end{array}$ & $\begin{array}{l}\text { Average } \\
\text { Variance } \\
\text { Extracted } \\
\text { (AVE) }\end{array}$ \\
\hline $\begin{array}{l}\text { Practitioner Lecturer } \\
\left(\mathrm{X}_{1}\right)\end{array}$ & 0,934 & 0.937 & 0.945 & 0.655 \\
\hline Industrial work $\left(\mathrm{X}_{2}\right)$ & 0,965 & 0.974 & 0.974 & 0.884 \\
\hline $\begin{array}{l}\text { Entrepreneurship } \\
\text { Competence }(\mathrm{Y})\end{array}$ & 0,956 & 0.962 & 0.964 & 0.819 \\
\hline
\end{tabular}

From the results of composite reliability, as shown in the table above, it can be seen that all composite reliability values in each construct have a value greater than 0.7 , which means that all constructs are reliable. 
Istiningsih

Likewise, when referring to the results of the calculation of the Cronbach's alpha value as shown in the table above, it can be seen that the Cronbach's alpha value of all constructs is greater than 0.7 , which means that all of the constructs are reliable.

\section{Data Analysis}

Data analysis is an attempt to organize data, sort it out in order to find patterns, and synthesize them into meaningful units (Miles et al., 2013). Analysis of quantitative data from questionnaires where the results of the analysis are in the form of simple linear regression.

Quantitative data analysis was carried out in four stages. First, collect data using the questionnaire method. The data collected was adjusted to the research theme, namely the influence of lecturer experience and industrial internships on entrepreneurial competence. Second, the data were tested for normality. Third, the data analysis technique is multiple linear regression with Smart PLS 3.0.

\section{Findings and Discussion}

To describe the data for each variable, cross-loading analysis was used. The crossloading value shows the magnitude of the correlation between each construct and its indicators and indicators from other block constructs. A measurement model has good discriminant validity if the correlation between the construct and its indicators is higher than the correlation with indicators from other block constructs. After processing the data using SmartPLS 3.0 the results can be seen as follows.

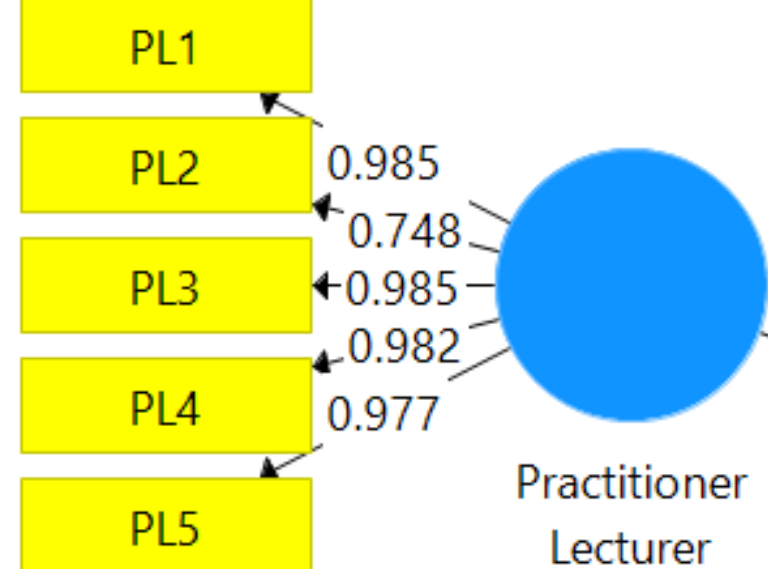

Diagram 1. cross loading Practitioner Lecturer

The results of the cross loading analysis on the Practitioner lecturer variable show that the best indicator is PL1 (having business experience), and PL3 (completing work well) of 0.985 , followed by PL4 (not making mistakes at work) of 0.882 . While the lowest indicator is PL2 (Has entrepreneurship targets and goals) of 0.748 


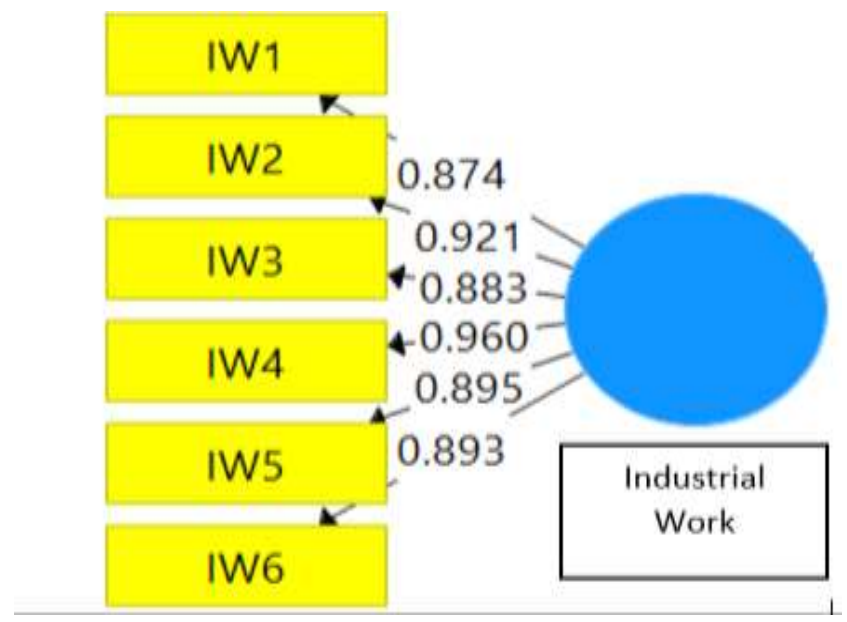

Diagram 2. Cross loading Industrial Work

The results of the cross-loading analysis show that the best indicator is IW4 (creativity) of 0.960 , followed by IW2 (attitudes and behaviors that are in line with the business world and industry) of 0.921 . While the lowest indicator is IW (mastery of skills) of 0.874

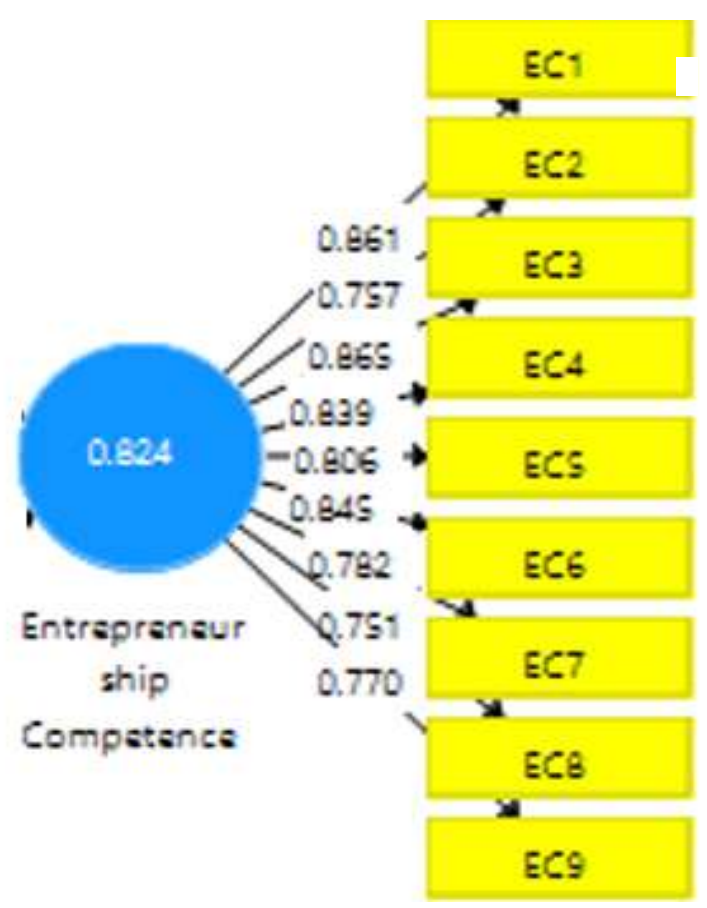

Diagram 3. Cross loading Entrepreneurship Competence

The results of cross-loading analysis on the Entrepreneurship Competence variable show that the best indicator is EC3 (ability to control risk) of 0.865 , followed by EC1 (knowledge of entrepreneurship) of 0.861 . While the lowest indicator is EC8 (integrity) of 0.751 . 
Istiningsih

\section{Hypothesis Test}

Based on the results of data analysis tests that have been carried out as well as several theories that have been described by experts, the results of this study are obtained as follows:

First Statistical Hypothesis:

$\mathrm{H}_{01}: \gamma_{1}=0 \quad$ : It is suspected that there is no influence between practitioner lecturers on entrepreneurship competence in Vocational students at the Islamic University of Indonesia.

$H a_{1}: \gamma_{1} \neq 0 \quad: \quad$ it is suspected that there is an influence between practitioner lecturers on entrepreneurship competence in vocational students at the Islamic University of Indonesia.

Hypothesis testing is carried out based on the results of the Inner Model (structural model) test which includes $r$-square output, parameter coefficients, and t-statistics. To see whether a hypothesis can be accepted or rejected, among others, by paying attention to the significance value between constructs, t-statistics, and p-values. The hypothesis testing of this research was carried out with the help of the SmartPLS (Partial Least Square) 3.0 software. These values can be seen from the bootstrapping results. The rule of thumb used in this study is t-statistic > 1.96 with a significance level of p-value $0.05(5 \%)$ and a positive beta coefficient. The value of testing this research hypothesis can be shown in Table 5 and the results of this research model can be described as shown in the following diagram.

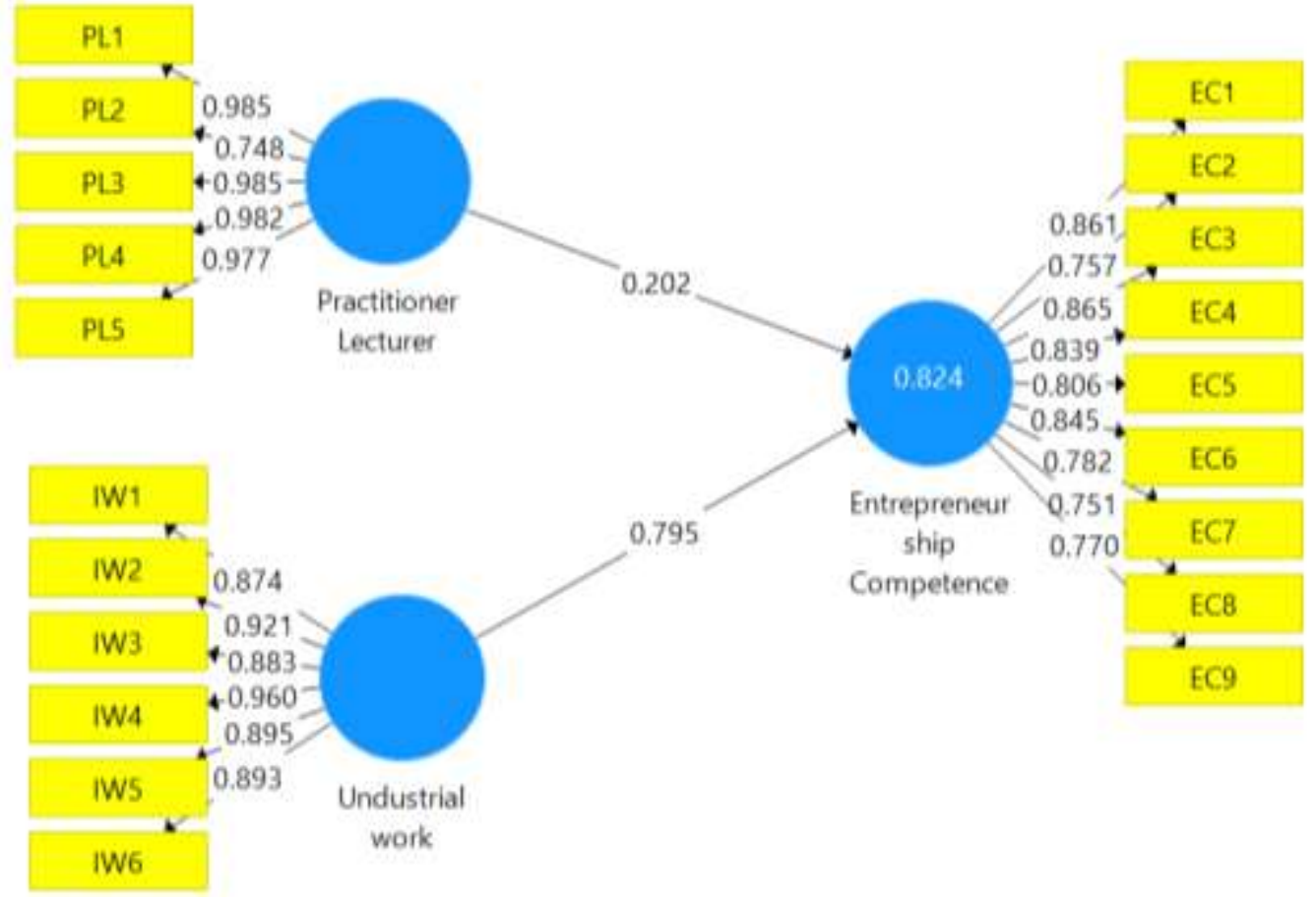

Diagram 4. Model of Research 
Based on the model of results of hypothesis testing, the path coefficient is 0.824 , with $\mathrm{R}$ of 0.824 and $\mathrm{R} 2$ of 0.821 . The results of the complete analysis can be seen in the following table.

Table 4. $\mathrm{R}^{2}$, T-test, and $\mathrm{P}$ Value

\begin{tabular}{llllll}
\hline Effect & $\begin{array}{l}\text { Original } \\
\text { Sample } \\
(\mathrm{O}) / \mathrm{R}^{2}\end{array}$ & $\begin{array}{l}\text { Sample } \\
\text { Mean } \\
(\mathrm{M})\end{array}$ & $\begin{array}{l}\text { Standard } \\
\text { Deviation } \\
(\mathrm{STDEV})\end{array}$ & $\begin{array}{l}\mathrm{T} \text { Statis tics } \\
(|\mathrm{O} / \mathrm{STDEV}|)\end{array}$ & $\begin{array}{l}\mathrm{P} \\
\text { Values }\end{array}$ \\
\hline $\mathrm{X}_{1} \rightarrow \mathrm{Y}$ & 0.331 & 0.346 & 0.062 & 3.850 & 0.000 \\
\hline $\mathrm{X}_{2} \rightarrow \mathrm{Y}$ & 0,792 & 0.346 & 0.062 & 3.850 & 0.000 \\
\hline $\mathrm{X}_{1} \mathrm{X}_{2} \rightarrow \mathrm{Y}$ & 0,824 & 0.346 & 0.062 & 3.850 & 0.000 \\
\hline
\end{tabular}

From the results of the first hypothesis test, the coefficient and $R$ Square $\left(R^{2}\right)$ are 0.331 with a t-statistic of $3.850>1.96$ with a p-value of $0.000<0.05$, so Ho1 is rejected and Ha1 is accepted. There is a significant influence between practitioner lecturers on entrepreneurship competence in vocational students at the Islamic University of Indonesia.

The value of the coefficient of determination shows that the value of $r$ square is 0.331 . This means that the ability of the practitioner lecturer variable affects $33.1 \%$ of the entrepreneurial competence variable. While the remaining $66.9 \%$ is influenced by other factors that are not intended in this study.

Second Hypothesis Test

$\mathrm{H}_{\mathrm{O} 2}: \gamma_{2}=0$ : It is suspected that there is no influence between industrial work on entrepreneurship competence in vocational students at the Islamic University of Indonesia.

$H_{a 2}: \gamma_{1} \neq 0$ : it is suspected that there is an influence between industrial work on entrepreneurship competence in vocational students at the Islamic University of Indonesia.

From the results of the first hypothesis test, the coefficient and R Square $\left(R_{2}\right)$ are 0.792 with a t-statistic of $3.850>1.96$ with a p-value of $0.000<0.05$, so $\mathrm{Ho} 2$ is rejected and $\mathrm{Ha} 2$ is accepted. There is a significant influence between industrial work on entrepreneurship competence in vocational students at the Islamic University of Indonesia.

The value of the coefficient of determination shows that the value of $r$ square is 0.792 . That is, the magnitude of the ability of the practitioner lecturer variable affects $79.2 \%$ of the entrepreneurial competence variable. While the remaining $20.8 \%$ is influenced by other factors that are not intended in this study. 
Istiningsih

Third Hypothesis Test

$\mathrm{H}_{03}: \gamma_{3}=0$ : It is suspected that there is no simultaneous influence between practitioner lecturer and industrial work on entrepreneurship competence in vocational students at the Islamic University of Indonesia.

$H_{a_{3}}: \gamma_{3} \neq 0$ : it is suspected that there is an influence between practitioner lecturer and industrial work simultaneously on entrepreneurship competence in vocational students at the Islamic University of Indonesia.

From the results of the first hypothesis test, the coefficient and $R$ Square $\left(R_{2}\right)$ are 0.824 with a t-statistic of $3.850>1.96$ with a p-value of $0.000<0.05$, so $\mathrm{Ho2}$ is rejected and $\mathrm{Ha} 2$ is accepted. There is a significant influence between practitioner lecturer and industrial work simultaneously on entrepreneurship competence in vocational students at the Islamic University of Indonesia.

The value of the coefficient of determination shows that the value of $r$ square is 0.824 . This means that the ability of the practitioner lecturer variable and the industrial internship program affects $82.4 \%$ of the entrepreneurial competence variable. While the remaining $17.6 \%$ is influenced by other factors that are not intended in this study. These factors include the business incubator program on campus, student passion in business, venture capital, family support, and others.

Based on the results of the simultaneous test, it can be seen that the $X_{2}$ variable, in this case, the industrial work learning method, has a greater influence than the practitioner lecturer. In other words, to improve students' entrepreneurial skills, it is better to send students to take part in internships in companies compared to assigning lecturers who have experience in entrepreneurship to teach entrepreneurship.

\section{E. Discussion}

Based on the results of the analysis above, it can be described that the research model that has been formed in order to improve students' entrepreneurial abilities is by assigning practitioner lecturers to teach entrepreneurship and sending students for internships in companies. Both models are proven to be able to improve student's abilities in the field of entrepreneurship. When the campus wants to improve the entrepreneurial skills of its students, it can include students in an internship program at the company. This model is more effective than assigning practicing lecturers who have experience in opening a business. When students join the internship program, they will get good business experience, starting from the procurement of raw materials, processing raw materials into products, packaging, marketing, product quality improvement, packaging improvement, market expansion, excellent service to customers, increasing the number of products sold, strategies to win the competition, and strategies to survive from various obstacles to doing business.

Meanwhile, when assigning practicing lecturers to teach, stories of success and ups and downs in business can only be visualized during teaching, while students only get 
stories and business descriptions without direct practice. When practitioners teach, students can only imagine without being able to be directly involved in the lecturer's business processes.

This condition causes the student internship model to be much better than assigning practitioners to teach. Thus, universities must carry out various forms of cooperation with the business world and the industrial world so that students are able to gain knowledge and experience in business when students participate in internship programs at companies in real terms. In other words, the active system model, in which students actively visit the company, is much more effective than the passive mode where students continue to study on campus, meanwhile, practitioners come to campus.

The results also show that the experience of lecturers has a simultaneous and partial effect on the entrepreneurial competence of vocational students at the Islamic University of Indonesia. Lecturer experience in entrepreneurship is important to improve student competence. Samuel (2014) states that the longer a person is in their field, the more they will be able to master and hone skills so that it will have an impact on how that person teaches others. With the experience of lecturers conducting business activities, it will lead to an increase in entrepreneurial competence which is a combination of attitudes, knowledge, and skills that are interconnected. Even in the presence of entrepreneurial competence, in research Sugandi \& Suhaeni (2019) mentioned that it will be able to affect the level of success of the business being carried out. So that the experience of lecturers doing entrepreneurship activities is very important in order to influence student competence in entrepreneurship.

In addition to the experience of lecturers, industrial internships obtained in this study can affect entrepreneurial competence. The results show that if an industrial internship is carried out, it can affect the increase in entrepreneurial competence because students not only learn about their vocational knowledge but in running a business in certain industries. As this research is in line with research of Bayu (2009) that entrepreneurship internships will create linkages and equivalence between universities and industry which are able to hone students' competence in entrepreneurship.

The results of the cross-loading analysis on the Practitioner lecturer model show that the best indicators are PL1 (having business experience), and PL3 (completing work well), meaning that if the university wants to use practitioner lecturers in improving student entrepreneurial competence, then the practitioner lecturer Must have experience in entrepreneurship with a high level of success. In addition, the practitioner lecturer must have a good track record, have never failed in entrepreneurship.

The results of the cross-loading analysis of the internship program variables show that the best indicator is IW 4 (creativity) and followed by IW 2 (attitudes and behaviors that are in harmony with the business world and the industrial world). Thus, when universities want to use the internship program model in improving students' entrepreneurial competencies, the apprenticeship programs that are developed should be able to stimulate the creativity of students whose internship students must have attitudes and behaviors that are in line with the work climate of the internship place. 
Istiningsih

The results of cross-loading analysis on the Entrepreneurship Competence variable

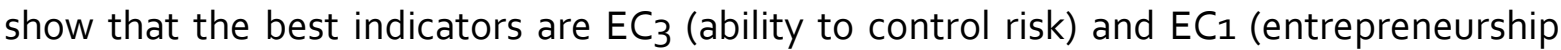
knowledge). This means, when universities want to improve student entrepreneurial competencies, the most emphasized aspect is the ability to control risk. The risk of entrepreneurship must be managed properly, not allowed to attack the sustainability of the business that is being carried out.

\section{F. Conclusion}

The results showed that the experience of lecturers in carrying out entrepreneurial activities was able to have a positive effect on the entrepreneurial competence of vocational students majoring in the Islamic University of Indonesia. In addition, industrial internships are also able to positively influence entrepreneurial competencies so that internship programs are needed in order to create reliable and creative, and innovative Human Resources. Then simultaneously, both the experience of lecturers and the industrial internship program are able to jointly influence the entrepreneurial competence of vocational students at the Islamic University of Indonesia.

\section{BIBLIOGRAPHY}

Abdullah, S. Bin. (2020). Entrepreneurship Education in Technical Vocational Education and Training (Tvet) and Models of Implementation. Journal MOHE, 1(10), 1-22.

Andayani, E. (2015). Analisis Pengalaman Belajar Kewirausahaan Terhadap Minat Berwirausaha Pada Program Smk Mini Pondok Pesantren. Prosiding Seminar Pendidikan Ekonomi Dan Bisnis, November.

Bagus, I. G., Satrya, H., \& Suwandana, I. G. M. (2015). Potensi Kewirausahaan Mahasiswa

Di Fakultas Ekonomi dan Bisnis Universitas Udayana. E-Jurnal Manajemen Unud, 4(12), 4559-4594.

Banu, S. H. B. (2009). Pengembangan Jiwa Kewirausahaan di Kalangan Dosen dan Mahasiswa. Jurnal Ekonomi Bisnis, 1(2), 114-122.

Boldureanu, G., Ionescu, A. M., Bercu, A. M., Bedrule-Grigoruță, M. V., \& Boldureanu, D. (2020). Entrepreneurship education through successful entrepreneurial models in higher education institutions. Sustainability (Switzerland), 12(3), 1-33. https://doi.org/10.339o/su12031267

Buana, Y., Hidayat, D., Prayogi, B., \& Vendy, V. (2017). The Effect of Entrepreneurship Education on Entrepreneurial Intention of University Students by Adopting Linan Model. Binus Business Review, 8(1), 67. https://doi.org/10.21512/bbr.v8i1.1958

Diana, O., Santoso, D., \& Rahmanto, A. N. (2010). Penerapan Nilai-nilai Wirausaha Pada Pengusaha Indie Clothing di Surakarta. Journal Article, 2(1), 1-29. https://media.neliti.com/media/publications/116906-ID-none.pdf

Disas, E. P. (2018). Link and Match sebagai Kebijakan Pendidikan Kejuruan. Jurnal Penelitian Pendidikan, 18(2), 231-242. https://doi.org/10.17509/jpp.v18i2.12965

Elizar. (2018). Kewirausahaan Di Perguruan Tinggi Akan. Edukasi Lingua Sastra, 16(1), 22- 
32. https://jurnal.umko.ac.id/index.php/elsa/article/view/75

Elwanas, Y. (2020). Prosiding seminar nasional pendidikan program pascasarjana universitas pgri palembang 10 januari 2020. Prosiding Seminar Nasional Pendidikan Program Pascasarjana Universitas Pgri Palembang, 599.

Genoveva. (2019). The Influence of Entrepreneurial Culture on Entrepreneurial Intention Among Business Students. Firm Journal of Management Studies, 4(1), 40-56. https://doi.org/10.33021/firm.v4i1.682

Kemenristekdikti. (2019). Kebijakan Baru Kemristekdikti Dalam Pendirian/Penggabungan Perguruan Tinggi dan Pembukaan Program Studi.

Kyguolienè, A., \& Švipas, L. (2019). Personal Entrepreneurial Competencies of Participants in Experiential Entrepreneurship Education. Management of Organizations: Systematic Research, 82(1), 37-51. https://doi.org/10.1515/mosr-2019-0012

Martyajuarlinda, P., \& Kusumajanto, D. D. (2018). Effect of Entrepreneurship Education and Self Efficacy Towards the Intention of Entrepreneurship. Jurnal Pendidikan Bisnis Dan Manajemen, 4(3), 142-152. https://doi.org/10.17977/umoo3v4i32018p142

Maula, F. A. (2017). Pengaruh pengalaman berwirausaha dan latar belakang pendidikan terhadap karakteristik kewirausahaan mahasiswa. Universitas Negeri Semarang.

Mayani, E., \& Syamsudin, H. (2011). Pengembangan Program Pembelajaran IPS untuk Peningkatan Keterampilan Sosial. Jurnal Penelitian, 9(1), 1-11.

Mudawama, N. (2018). Upaya Guru Kewirausahaan Dalam Meningkatkan Minar Berwirausaha Siswa SMK 1 Wonorejo Pasuruan. Universitas Islam Negeri Maulana Malik Ibrahim Malang.

Muhson, A., Wahyuni, D., \& Mulyani, E. (2012). Analisis Relevansi Lulusan Perguruan Tinggi Dengan Dunia Kerja. Jurnal Economia (Yogyakarta), 8(1), 42-52. https://doi.org/10.21831/economia.v8i1.800

Mustikawati, A., \& Kurjono, K. (2020). Studi tentang Pengaruh Pembelajaran Kewirausahaan Terhadap Minat Berwirausaha Siswa di Era Revolusi 4.0. SOCIA: Jurnal Ilmu-Ilmu Sosial, 17(1), 31-37. https://doi.org/10.21831/socia.v17i1.33048

Naudé, W. (2010). Promoting Entrepreneurship in Developing Countries: Policy Challenges. United Nations University, 1(4), 1-8.

Nurjaya, N., Sobarna, A., Affandi, A., Erlangga, H., \& Sarwani, S. (2020). Edupreneurship management in shaping the nation's character. Jurnal Konseling Dan Pendidikan, 8(3), 198. https://doi.org/10.29210/151200

Prabandari, E. T., \& Rasyid, A. (2015). Pengaruh pembelajaran kewirausahan melalui business center, prakerin, dan latar belakang keluarga terhadap kompetensi berwirausaha. Jurnal Pendidikan Vokasi, 5(1), 1. https://doi.org/10.21831/jpv.v5i1.6054

Rifa'i, A., \& Nugraha, E. (2019). Rencana Strategi Dalam Menerapkan Pendidikan Kewirausahaan Di Perguruan Tinggi Melalui Proses Pembelajaran yang Berkelanjutan. Jurnal Manajemen Dan Bisnis, 1(1), 1-19.

Samuel. (2014). Pengaruh Kompetensi, Komitmen, dan Pengalaman Terhadai Kinerja Dosen. Jurnal Bisnis Dan Ekonomi (JBE), 21(2), 149-163.

Sugandi, F., \& Suhaeni, T. (2019). Peran Kompetensi Kewirausahaan dalam Meningkatkan 
Istiningsih

Kinerja Usaha pada Industri Kreatif Subsektor Kerajinan di Kota Bandung. Prosiding Industrial Research Workshop, 1(1), 1374-1386.

Sukoco, J. B., Kurniawati, N. I., Werdani, R. E. (2019). Pemahaman Pendidikan Vokasi. Jurnal Pengabdian Vokasi, 01(01), 23-26.

Susilaningsih. (2015). Pendidikan Kewirausahaan Di Perguruan Tinggi: Pentingkah Untuk Semua Profesi? Jurnal Economia, 11(1), 1. https://doi.org/10.21831/economia.v11i1.7748

Taufik, Y. (2019). Peran Dosen Pengampu Mata Kuliah Entrepreneurship Terhadap Minat Mahasiswa Membuka Usaha di Politeknik LP3 Bandung. ATRABIS: Jurnal Administrasi Bisnis, 1(1), 138-145.

Yohana, C. (2020). Factors influencing the development of entrepreneurship competency in vocational high school students: A case study. International Journal of Education and Practice, 8(4), 804-819. https://doi.org/10.18488/journal.61.2020.84.804.819 